\title{
Patiënteninformatie Mond- en Kaakziekten
}

\section{Spatadertjes}

In de mond en op de lippen kunnen vooral op wat oudere leeftijd spatadertjes ontstaan. In vaktaal wordt gesproken over flebectasieën of varices.

Spatadertjes zijn plaatselijke, volledig onschuldige verwijdingen van kleine bloedvaten. Soms gaat het om een enkel blauw zwellinkje, maar soms is sprake van meerdere spatadertjes. De grootte kan variëren van enkele millimeters tot soms wel een centimeter.

Spatadertjes in de mond veroorzaken geen klachten en kunnen verder geen kwaad. Er is dan ook geen reden om ze te verwijderen, tenzij het niet helemaal zeker is of het wel een spatadertje is. In dat geval kan het zwellinkje op eenvoudige wijze onder plaatselijke verdoving worden verwijderd voor weefselonderzoek door de patholoog. Bij lokalisatie op boven- of onderlip vragen patiënten soms om verwijdering om esthetische redenen.

\section{Wat kunt u zelf doen?}

Er is bij het optreden van spatadertjes niets wat u zelf kan doen. $\mathrm{U}$ hoeft niet bang te zijn voor onverwachte bloedingen.
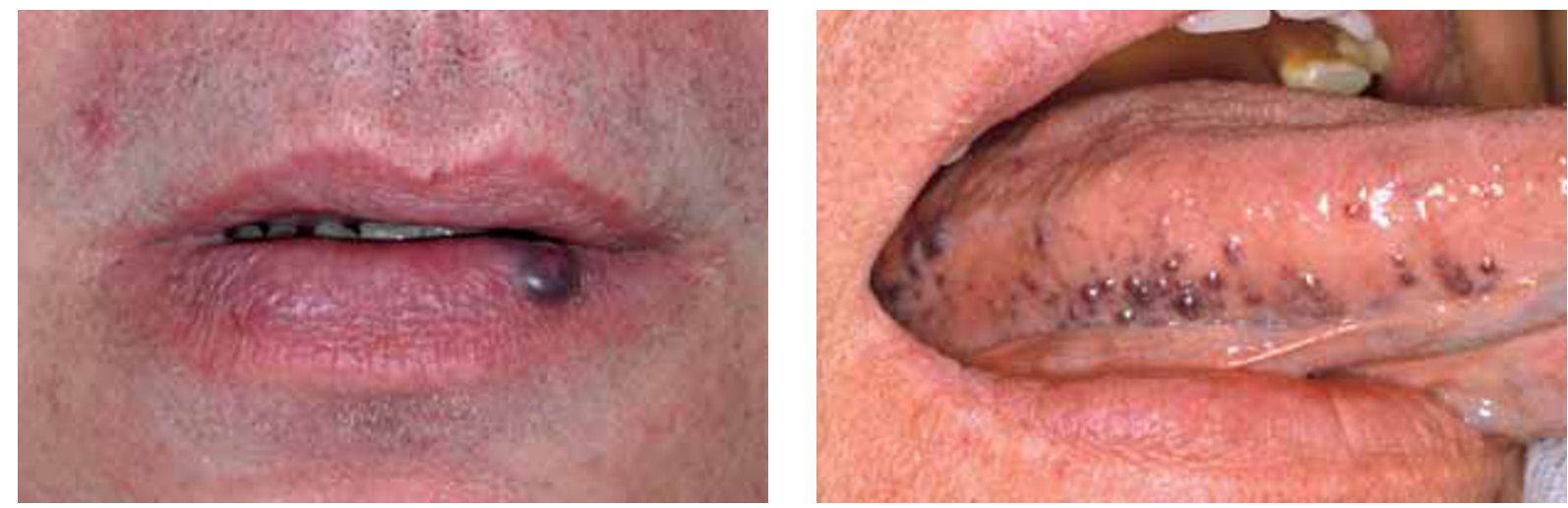